\title{
CO-PRODUCTION OF INNOVATIVE PUBLIC SERVICES - A THEORETICAL BACKGROUND
}

\author{
Urszula Kobylińska \\ Bialystok University of Technology, Poland
}

\begin{abstract}
Co-production is currently one of the pillars of the public sector reform around the world. The potential of this concept is increasingly recognized in the design and improvement of public services in cities. Co-production is a partnership among citizens, public institutions and enterprises, which enables all the parties to be more involved in the management of the city and contributes to greater control over public resources (Horne \& Shirley, 2009). In the subject literature, it is pointed out that these reforms are directed to the implementation of effective public services, are a response to the deficit of active citizenship and active communities and enterprises that are insufficiently involved in the processes of designing and co-creating innovative public services in cities. The basic - and basically still valid today conceptualization of co-production was carried out in several works published in the first half of the 1980s. The aim of this paper is to analyse the state of research on the issue of coproduction in public services and to identify the main research areas related to this subject. The paper was based on a systematic review of literature, which included, among others, the emergence of basic literature and selection of publications, bibliometric analysis and content analysis. The results of the conducted research show that the issue of co-production in public services is a new subject, still not well recognized in the literature and which may constitute a current and interesting area of research.
\end{abstract}

Keywords: co-production, innovations in public sector, public services.

\section{Introduction}

Co-production is now an innovative approach to changes in the way public sector services are provided, based on establishing new relationships among citizens, public institutions and enterprises that enable all the parties to become more involved in the management of public services and contribute to greater control over public resources (Horne \& Shirley, 2009). Co-production is currently one of the pillars of the public policy reform around the world and is part of the trend of contemporary innovative public management (Bovaird, 2007).

The literature on the subject indicates that these reforms are directed to the implementation of effective public services and are a response to the deficit of active citizenship and enterprises that are insufficiently involved in the processes of designing and co-creating innovative public services (Sienkiewicz-Małyjurek, 
2016). The literature indicates also some assumptions justifying the development of the idea of co-production in the provision of public services (Stokłuska, 2017):

- $\quad$ the needs of citizens are more effectively met when they themselves are involved in cooperation with service providers;

- $\quad$ the recipients of services often play a key role in the problem-solving process;

- $\quad$ the main beneficiaries involved in this approach are the beneficiaries themselves, their families, the social groups they belong to, local entrepreneurs - cooperating with professional service providers, including institutions managing individual public services.

The aim of this paper is to analyse the state of research and research trends in the area of co-production - an innovative concept of management in the public sector and to identify the main research areas related to this subject in economic sciences. The paper was based on a systematic review of literature, which included, among others, the emergence of basic literature and the selection of publications according to accepted criteria, bibliometric analysis and content analysis. The first part of the paper presents the literature definitions of the subject of the research and the research method. In the further part of the study, the results of the analysis of bibliometric data of world literature with regard to the time factor, the frequency of publication and the scope of the problem under analysis were presented. Next, the results of the conducted research were discussed, the conclusions drawn and the limitations of existing research indicated.

\section{Co-production in innovative public services - a literature review}

In foreign literature on the subject, co-production becomes one of the most important topics concerning innovative management in the public sector (Bovaird 2007; Bovaird \& Löffler 2012; Alford, 2009; Osborne \& Brown, 2011). The co-production assumes that residents engage their own time and effort in producing public services that they will use themselves (as opposed to volunteering, where citizens are involved for other people) (Verschuere, Brandsen, \& Pestoff 2012). The general idea of co-production was initiated in several works published in the first half of the 1980s. According to Brudney and England, who at that time attempted to define the phenomenon of co-production, they noticed that the work on conceptualization was carried out in two strands: the first were economic analyses, the second one was run by political scientists dealing with public administration (Kaźmierczak, 2014). The effects of these works retain their value to this day - creating the foundation for studies in later 
years, including today. The co-production theory prepared by economists at Indiana University at that time seems particularly important - in their view, the concept of co-production refers to "ordinary" citizens and their direct involvement in the process of producing services (Parks et al., 1981). An important definition for the development of co-production concepts is the one adopted in the OECD report, which indicates that it is: a way of planning, designing, delivering and evaluating public services that uses direct input from citizens, service recipients and civil society organizations (Together for Better Services, 2011). From this definition, according to its authors, it follows that: the scope of tasks of recipients of services - citizens within the framework of coproduction is very wide and ranges from the simplest activity, which is simple feedback about the service, to long-lasting and rich in content relations with professional service providers; co-production is something other than contracting public services in the private sector (e.g. through outsourcing) - if co-production is based on the undefined / open scope of inviting citizens to participate, contracting services requires a formal agreement with its provider and its precise specification; the basis for co-production practices is the voluntary involvement of citizens (Together for Better Public Services, 2011).

The consequence of the increase in interest in co-production observed for around 17 years has become the extension of the meaning of this concept and the justification of its applicability at each stage of the process of managing public services. Researchers point out that the contemporary concept of coproduction refers to areas such as: (1) launching a service that includes policy planning, prioritization, financing methods; (2) service design; (3) providing a service that includes: management and service provision; (4) evaluations (including monitoring and evaluation) (Voorberg, Bekkers, \& Tummers 2014).

As V. Pestoff notes: the definitions of co-production fall within the range from the "mix of contributions that public service agents and citizens bring to public services" to "partnership between citizens and providers of public services". In the differences between them - according to Pestoff - there are cultural differences, differences in focus, or both. Above all, however, differences in the definition of co-production prove that its researchers and observers have taken different points of view, which leads to a better understanding of the phenomenon and an ever-more visible perception of its complexity (Pestoff, 2012). Sienkiewicz-Małyjurek cites the results of international surveys confirming that co-production affects the innovation of services, and the basic determinants in this respect are: the level of involvement of local communities, the level of structuring solutions and the ability to cooperate (Sienkiewicz-Małyjurek, 2016). Similarly, in the work of Kaźmierczak, we can read about the results of various surveys conducted in European countries confirming that co-production practices occur in all analysed 
public services categories, albeit not at the same intensity, e.g. co-production mainly occurs in the planning and direct delivery of public services, and depending on the type of services. Of Europeans, $70 \%-80 \%$ would be willing to engage in activities that improve the quality of public services, in particular health (Kaźmierczak, 2014). As the quoted author points out, undoubtedly empirical research on the phenomenon of co-production has not yet emerged from a very initial, "exploratory" phase, and is therefore incomplete in the state of reliable knowledge about, on the one hand, its scale, forms, conditions, on the other - about attitudes towards her and their determinants. The above-mentioned research shows that co-production is a real, innovative approach to the process of providing public services, which is affected by many different factors, which may take various forms of cooperation. There is a large research potential to explore this phenomenon.

\section{Research methodology}

The aim of this paper is to analyse the state of research and research trends in the area of co-production - an innovative concept of management in the public sector and to identify the main research areas related to this subject in economic sciences. The research method used in the evaluation of publications in the field of co-production of innovative public services was a systematic review of literature using bibliometric analysis techniques. A distinctive feature of the systematic review of literature is verifiable and reliable due to the rigor of methodical review of the state of knowledge and the use of quantitative techniques of description and analysis of literature (Klincewicz, 2008). For the needs of bibliometric analysis, such research techniques were used as: analysis of trends by means of time series, citation analysis, identification of researchers and centres from which the main research trends originated, and general analysis of the content of the most frequently quoted publications.

The scope of the literature research was as follows: (1) the subject of the study was selected; (2) analysis of changes in the number of publications in subsequent years and an analysis of the citations from the analysed subject matter in the Scopus and Web of Science databases; (3) key publications in the databases have been identified and the journal IF has been assessed; (4) main investigators and countries of origin were identified; (5) the contents of the publication were analysed in terms of specific areas of research / research methods. 


\section{Findings}

Data for the research study of co-production in public services were collected from Web of Science and Scopus databases in the first quarter of 2018. Determining the literature of the subject was aimed at establishing a set of publications that are the source of further analysis. In the initial phase of the research, scientific publications were searched, which included in their title, abstract or key words the expression "co-production" and then "co-production in public services". The review included publications from 2000 to 2017 and was limited to the field of economic sciences. The total number of found documents for "co-production" in the Web of Science database was 3398 and for Scopus 5233. After narrowing down the search for "co-production in public services" and the area of business and management, the number of publications decreased to 48 in the Scopus database and 47 in Web of Science.

Table 1 Criteria and search areas of the literature database for co-production in public services (source: own study based on records from WoS databases, Scopus. Date of searching: 2018-01-30)

\begin{tabular}{|l|c|c|}
\hline \multicolumn{1}{|c|}{ Criterion of analysis } & Number of found publications \\
\hline \multicolumn{1}{|c|}{$(1)$} & Scopus & $\begin{array}{c}\text { Web of } \\
\text { Science }\end{array}$ \\
\hline $\begin{array}{l}\text { Criterion 1: “co-production” (in the title, abstract, key } \\
\text { word) }\end{array}$ & 5233 & 3398 \\
\hline $\begin{array}{l}\text { Criterion 2: “co-production in public services” (in the } \\
\text { title, abstract, key word) }\end{array}$ & 277 & 213 \\
\hline Criterion 3: publications in the field of social sciences & 136 & 154 \\
\hline $\begin{array}{l}\text { Criterion 4: publications in the field of economics and } \\
\text { management }\end{array}$ & 71 & 57 \\
\hline $\begin{array}{l}\text { Criterion 5: papers in journals in the field of economics } \\
\text { and management }\end{array}$ & 48 & 47 \\
\hline
\end{tabular}

In fact, by 2000, only 3 publications from the analysed topic were identified in the WoS database. There is an increased interest of researchers in co-production after 2000. Information on the number of publications from the analysed topic for economic sciences (area: business, economics, management) in the Scopus and Web of Science databases is presented in Figure 1. As can be seen in the graph, after a period of stagnation in the years 2002-2010, the number of publications was systematically growing, and in the last two years (2016-2017) their number was relatively high. 


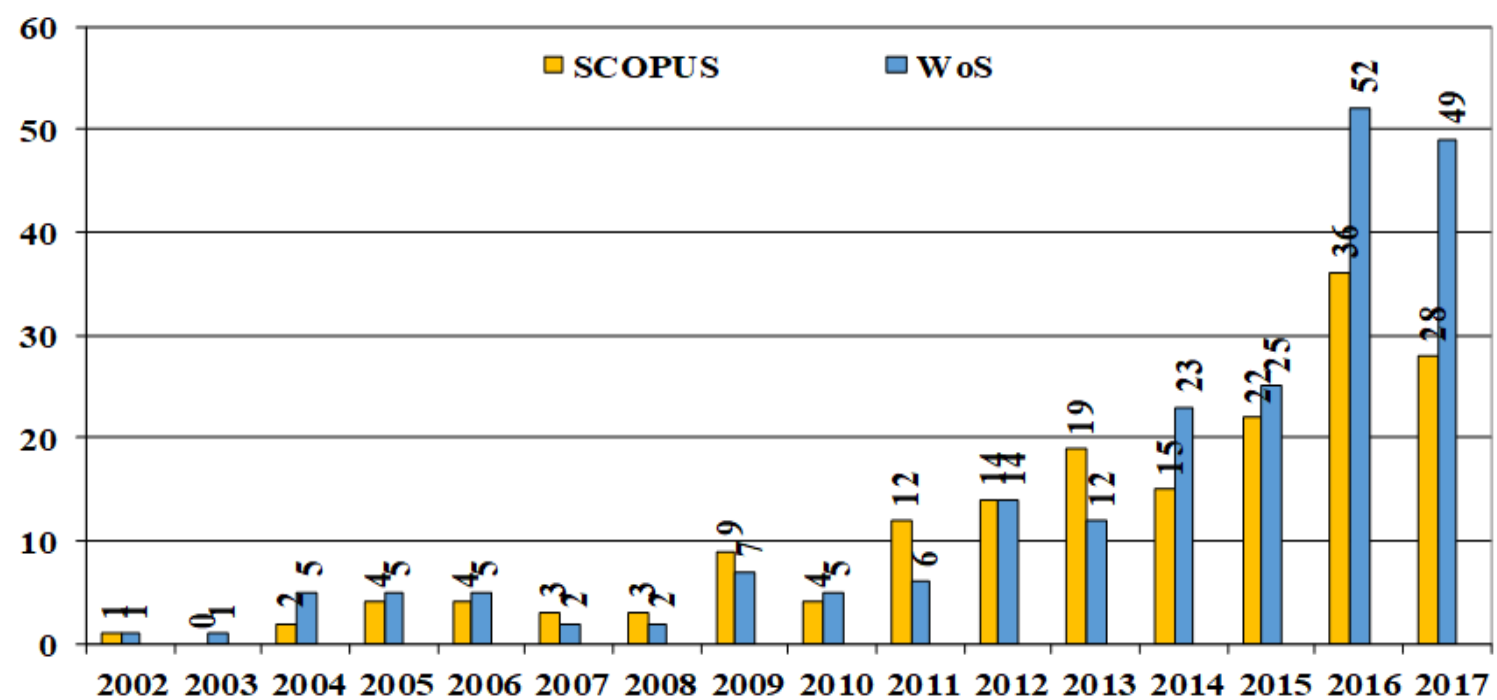

Figure 1. Number of publications for the key word - "co-production in public services" in the title, key word or summary in the SCOPUS and WoS databases (source: own study based on the WoS and Scopus databases. Date of search 10-01-2018)

After the first conceptualization of the co-production phenomenon (1990s), in subsequent years (beginning of 2000), researchers began to analyse the possibilities of using it in various areas of the public sector (social care, health care, city management) and tried to indicate the main motives, processes and effects of applying the concept. The current challenges in the literature are twofold. First of all, there is still no empirical and comparative research that tests the assumptions related to co-production, its possibilities in generating social capital, new relations within the cooperation network, common motives for the behaviour of co-producers. Co-production research also suffers from a low methodological diversity (there is too little quantitative comparative work) (Verchuere et al., 2012).

In a further stage of the research, bibliometric analysis was limited to the analysis of quotability, taking into account publications issued in the years 20002017 and limiting them only to scientific papers. The largest number of papers on the subject studied in the Scopus database were published in the journals: Public Management Review ${ }^{1}$ (22), Voluntas ${ }^{2}$ (10), International Review of Administrative Science ${ }^{3}$ (7), International Journal of Public Administration ${ }^{4}$ (6), Government Information Quarterly ${ }^{5}(5)$. The most frequently quoted authors

${ }^{1} 2016$ - Impact Factor: 2.293

22016 - Impact Factor: 1.098

32016 - Impact Factor: 1.350

${ }^{4} 2016$ - Impact Factor: 1.133

52016 - Impact Factor: 4.090 
are: V. Pestoff (Ersta Skondal University College, Sweden) (quoted 509 times); T. Brandsen (Tilburg University, the Netherlands) (304 times); T. S. P. Osborne (University of Edinburgh Business School, Scotland) (237 times), T. Bovaird (University of Birmingham, the United Kingdom) (112 times); J. Alford (University of Melbourne, Australia) (107 times), E. Loeffler (University of Birmingham, WB) (85 times) ${ }^{6}$. The most cited papers come from researchers from countries such as the United Kingdom (96 publications), the United States (35), the Netherlands (25), Australia (25), Italy (21).

In a further stage of the research, bibliometric analysis was made to analyse the content of the most cited papers, dealing with the issue of co-production in public services. Attention was paid to such aspects as: the area of research / analysis, the type of public service being the subject of the analysis, applied research methods.

Table 2 summarizes the most cited publications together with the main research topics.

Table 2 The most-cited papers on co-production issues and exploration areas (source: own study based on the WoS and Scopus databases. Date of search 10-01-2018)

\begin{tabular}{|c|c|c|c|c|c|}
\hline No & $\begin{array}{l}\text { Author/ } \\
\text { Authors }\end{array}$ & $\begin{array}{c}\text { The title of the } \\
\text { publication/ journal }\end{array}$ & $\begin{array}{l}\text { The } \\
\text { number of } \\
\text { citations in } \\
\text { the Scopus } \\
\text { database }\end{array}$ & $\begin{array}{l}\text { The } \\
\text { number of } \\
\text { citations in } \\
\text { the WoS } \\
\text { database }\end{array}$ & $\begin{array}{l}\text { Main areas of } \\
\text { research }\end{array}$ \\
\hline (1) & (2) & (3) & (4) & (5) & \\
\hline 1 & $\begin{array}{l}\text { Brandsen, T., } \\
\text { Pestoff, V. }\end{array}$ & $\begin{array}{l}\text { Co-production, the } \\
\text { third sector and the } \\
\text { delivery of public } \\
\text { services. An } \\
\text { introduction, Public } \\
\text { Management Review } \\
\text { 8(4), 2006, pp. 493- } \\
\text { 501. }\end{array}$ & 142 & 120 & $\begin{array}{l}\text { Research into the role } \\
\text { of the third sector in } \\
\text { co-production of } \\
\text { public services. } \\
\text { Demonstration of } \\
\text { differences between } \\
\text { co-production, co- } \\
\text { management and co- } \\
\text { governance in the } \\
\text { criterion of citizen } \\
\text { involvement. }\end{array}$ \\
\hline
\end{tabular}

${ }^{6}$ Compilation based on the Scopus database dated: 2018-01-30 


\begin{tabular}{|c|c|c|c|c|c|}
\hline 2 & $\begin{array}{l}\text { Joshi, A., } \\
\text { Moore, M. }\end{array}$ & \begin{tabular}{|l|} 
Institutionalized co- \\
production: \\
Unorthodox public \\
service delivery in \\
challenging \\
environments, 2004, \\
Journal of \\
Development Studies \\
$40(4)$, pp. $31-49$. \\
\end{tabular} & 134 & 108 & $\begin{array}{lr}\text { Developing } & \text { the } \\
\text { concept } & \text { and } \\
\text { definition } & \text { of } \\
\text { institutionalized } & \text { co- } \\
\text { production. } & \end{array}$ \\
\hline 3 & Pestoff, V. & $\begin{array}{l}\text { Citizens and co- } \\
\text { production of } \\
\text { welfare services. } \\
\text { Childcare in eight } \\
\text { European countries, } \\
\text { Public Management } \\
\text { Review, 2006, } 8 \text { (4), } \\
\text { pp. 503-519. }\end{array}$ & 120 & 94 & $\begin{array}{l}\text { Co-production studies } \\
\text { in the area of } \\
\text { childcare services in } \\
\text { Europe. Comparative } \\
\text { empirical research. }\end{array}$ \\
\hline 4 & $\begin{array}{l}\text { Osborne, S. P., } \\
\text { Strokosch, K. }\end{array}$ & \begin{tabular}{|l|} 
It takes two to \\
tango? \\
Understanding the \\
co- \\
production of public \\
services by \\
integrating the \\
services management \\
and public \\
administration \\
perspectives, British \\
Journal of \\
Management, 2013 \\
24 (S3), pp. 31-47. \\
\end{tabular} & 75 & 51 & $\begin{array}{l}\text { Research on the } \\
\text { factors determining } \\
\text { the process of } \\
\text { providing innovative } \\
\text { services using co- } \\
\text { production, taking } \\
\text { into account the } \\
\text { integrated approach: } \\
\text { service management } \\
\text { and the perspective of } \\
\text { public administration. }\end{array}$ \\
\hline 5 & $\begin{array}{l}\text { Dunston, R., } \\
\text { Lee, A., Boud, } \\
\text { D., Brodie, P., } \\
\text { Chiarella, M. }\end{array}$ & $\begin{array}{l}\text { Co-production and } \\
\text { health system reform } \\
\text { - From re-imagining } \\
\text { to re-making, } \\
\text { Australian Journal of } \\
\text { Public } \\
\text { Administration, } \\
2009,68 \text { (1), pp. 39- } \\
52 .\end{array}$ & 70 & 51 & $\begin{array}{l}\text { The paper discusses } \\
\text { the possibilities and } \\
\text { challenges associated } \\
\text { with the co- } \\
\text { production of health } \\
\text { care services. } \\
\text { Identifies the co- } \\
\text { production discourse } \\
\text { and issues critical to } \\
\text { the successful } \\
\text { implementation of co- } \\
\text { production in the } \\
\text { health sector. }\end{array}$ \\
\hline
\end{tabular}




\begin{tabular}{|c|c|c|c|c|c|}
\hline 6 & King, S. F. & \begin{tabular}{|l|} 
Citizens as \\
customers: Exploring \\
the future of CRM in \\
UK local \\
government, \\
Government \\
Information \\
Quarterly, 2007, 24 \\
(1), pp. 47-63. \\
\end{tabular} & 70 & No data & $\begin{array}{l}\text { The paper describes } \\
\text { how selected public } \\
\text { institutions in the UK } \\
\text { plan to use CRM to } \\
\text { better understand the } \\
\text { needs of citizens, } \\
\text { involving them in the } \\
\text { co-production of local } \\
\text { affairs. }\end{array}$ \\
\hline 7 & $\begin{array}{l}\text { Verschuere, B., } \\
\text { Brandsen, T., } \\
\text { Pestoff, V. }\end{array}$ & $\begin{array}{l}\text { Co-production: The } \\
\text { State of the Art in } \\
\text { Research and the } \\
\text { Future Agenda, } \\
\text { Voluntas 2012, } 23 \\
\text { (4), pp. 1083-1101. }\end{array}$ & 63 & 53 & $\begin{array}{l}\text { Discussion of the } \\
\text { current state of } \\
\text { research on co- } \\
\text { production in public } \\
\text { services, in particular: } \\
\text { motives, effects and } \\
\text { efficiency of co- } \\
\text { production }\end{array}$ \\
\hline 8 & $\begin{array}{l}\text { Pestoff, V., } \\
\text { Osborne, S. P., } \\
\text { Brandsen, T. }\end{array}$ & \begin{tabular}{|l|} 
Patterns of co- \\
production in public \\
services. Some \\
concluding thoughts, \\
Public Management \\
Review, 2006, \\
8 (4), pp. 591-595.
\end{tabular} & 52 & 34 & $\begin{array}{l}\text { The role of the third } \\
\text { sector in involvement } \\
\text { in co-production is } \\
\text { examined. }\end{array}$ \\
\hline
\end{tabular}

The review of the content in the papers shows that co-production is a practice that can be found in many areas of the public sector (such as regional media, library services or garbage collection), but mainly in health care and education. Co-production was usually studied in single or comparative case studies. These case studies were often carried out using interviews and document analysis. Quantitative methods have been used much less frequently. In this connection, we can see that the qualitative approach prevails when examining co-production practices. This means, among others that the context of co-creation is examined and factors in this context have been the subject of special attention.

\section{Conclusions}

The results of analyses carried out in this paper show that the issue of coproduction in public services as an innovative concept of providing public services is still poorly recognized and without a solid empirical basis. In particular, national studies do not yet have significant achievements in this field, taking into account the recognisability and citation of publications in important scientific periodicals. 
While the causes of co-production development are well recognized in the literature on the subject: an attempt to improve the quality of public services by using the knowledge of users and their networks; the need to provide public services that are better targeted and respond better to users; the possibility of using co-production as a way to reduce costs; the opportunity to create synergies between the government and civil society with a positive impact on social capital, however, it is not enough space to study the effectiveness and efficiency of co-production, and the social effects of co-production. In addition to the limitations of traditional models of service provision, due to citizens' needs and to favourable political and institutional conditions, this way of providing public services will inspired, in many countries, the creation of more democratic decisions on future of e.g. cities.

We cannot yet clearly assert argument that co-production 'is the best of all possible alternatives' to improve the provision of public services through users' participation in the design, implementation and evaluation of public policies. More empirical evidences are needed to confirm that. Moreover, it is important to proceed with this analysis but this time focussing on the theory of services proposed by Osborne, thus cementing theoretical knowledge in this field. This knowledge should also be expanded to other industries and other social, political and economic realities (Silvestre et al., 2016).

\section{References}

Alford, J. (2009). Engaging public sector clients. From service delivery to co-production. New York: Palgrave Macmillian.

Bovaird, T. (2007). Beyond Engagement and Participation: User and Community Coproduction of Public Services. Public Administration Review, Volume 67, Issue 5. doi: 10.1111/j.1540-6210.2007.00773.x

Bovaird, T., \& Löffler, E. (2012). From Engagement to Co-Production. How Users and Communities Contribute to Public Service. In: V. Pestoff, T. Brandsen, B. Verschuere (Eds.) New Public Governance, the Third Sector and Co-Production. New York: Routledge.

Brandsen, T., \& Pestoff, V. (2006). Co-production, the third sector and the delivery of public services. An introduction. Public Management Review 8 (4), 493-501. doi.org/10.1080/14719030601022874

Dunston, R., Lee, A., Boud, D., Brodie, P., \& Chiarella, M. (2009). Co-production and health system reform - From re-imagining to re-making. Australian Journal of Public Administration, 68 (1), 39-52. doi: 10.1111/j.1467-8500.2008.00608.x.

Horne, M., \& Shirley, T. (2009). Co-production in public services: a new partnership with citizens. London: Cabinet Office.

Fledderus, J., Brandsen, T., \& Honingh, M. (2013). Restoring Trust Through the CoProduction of Public Services: A theoretical elaboration. Public Management Review, Vol. 16, Issue: 3, 3-20. doi.org/10.1080/14719037.2013.848920 
Joshi, A., \& Moore, M. (2004). Institutionalized co-production: Unorthodox public service delivery in challenging environments, Journ al of Development Studies, 40 (4), 31-49. doi: 10.1080/00220380410001673184

Kaźmierczak, T. (2014). Koprodukcja usług publicznych. Retrieved from http://www.eapn.org.pl/wp-content/uploads/2014/06/EAPN_ekspertyza_TK.pdf

King, S. F. (2007). Citizens as customers: Exploring the future of CRM in UK local government, Government Information Quarterly, 24 (1), 47-63. doi:10.1016/ j.giq.2006.02.012

Klincewicz, K. (2008). Polska innowacyjność. Analiza bibliometryczna. Warszawa: Wydawnictwo Naukowe WZ UW.

Osborne, S. P., \& Strokosch, K. (2013). It takes two to tango? Understanding the coproduction of public services by integrating the services management and public administration perspectives, British Journal of Management, 24 (S3), 31-47. doi: 10.1111/1467-8551.12010

Osborne, S., \& Brown, L. (2011). Innovation, public policy and public services delivery in the UK: the word that would be king? Public Administration, Vol. 89, No. 4, 1335-1350, doi: 10.1111/j.1467-9299.2011.01932.x

Parks, R. B., Baker, P. C., Kiser, L., Oakerson, R., Ostrom, E., Ostrom, V., Percy, S. L., Vandivort, M. B., Whitaker, G. P., \& Wilson, R. (1981). Consumers as coproducers of public services: some economic and institutional consideration. Policy Studies Journal. Vol. 9, 1001-1011, doi:10.1111/psj.1981.9.issue-7.

Pestoff, V. (2006). Citizens and co-production of welfare services. Childcare in eight European countries. Public Management Review, 8 (4), 503-519. doi: 10.1080/ 14719030601022882

Pestoff, V., Osborne, S. P., \& Brandsen, T. (2006). Patterns of co-production in public services. Some concluding thoughts, Public Management Review, 8 (4), 591-595. doi.org/10.1080/14719030601022999

Pestoff, V. (2012). Co-Production and the Third Sector Social Services in Europe. Some Crucial Conceptual Issues. In: V. Pestoff, T. Brandsen, B. Verschuere (Eds.) New Public Governance, the Third Sector and Co-Production, Routledge.

Sienkiewicz-Małyjurek, K. (2016). Innowacyjność koprodukcji w zarządzaniu publicznym na poziomie lokalnym. Zeszyty Naukowe Politechniki Śląskiej, 89, 421-435.

Silvestre, H. C., Catarino, J. R., \& Araujo, J. F. (2016). Evidence of co-production in public service provision: the case of the administrative arbitration centre in Portugal. Revista de Administração, 51 (4), 355-365. doi.org/10.1016/j.rausp.2016.07.007

Stokłuska, E. (2017). Czy mieszkańcy moga być koproducentami usług publicznych? http:///C:/Users/Urszula/Desktop/ENTREPREUNERSHIP/co-productionMB/LivingLab/8_ewa\%20stokluska.pdf [19-01-2018]

Strand, R., \& Ducournau, P. (2009). Trust, distrust and co-production: the relationship between research, biobanks and donors. The ethics of research biobanking, 115-130. Springer-Verlag. doi.org/10.1007/978-0-387-93872-1

Together for Better Public Services: Partnering with Citizens and Civil Society (2011). OECD Public Governance Reviews.

Verschuere, B., Brandsen, T., \& Pestoff, V. (2012). Co-production: The State of the Art in Research and the Future Agenda. VOLUNTAS: International Journal of Voluntary and Nonprofit Organizations, Vol 23, No 4, 1083-1101, doi:10.1007/s11266-012-9307-8

Voorberg, W. H., Bekkers V. J. J. M., \& Tummers, L. G. (2014). A systematic review of Cocreation and Co-production. Embarking on the social innovation journey. Public 
Kobylińska, 2018. Co-Production of Innovative Public Services - a Theoretical Background

Management Review. Vol. 17, Issue: 9, 1333-1357. doi.org/10.1080/14719037.2014. 930505

Wasiluk, A. (2016). Zaufanie a współpraca pomiędzy podmiotami gospodarczymi a instytucjami samorządowymi. In: B. Lubas, D. Hryszkiewicz, M. Borowik (Eds.), Kierunki doskonalenia koncepcji zarządzania organizacja publiczną. Teoria i praktyka. Szczytno: Wyższa Szkoła Policji. 